\title{
KLUCZOWE KOMPETENCJE KADRY KIEROWNICZEJ PRZEDSIĘBIORSTW SEKTORA HI-TECH. DIAGNOZA LUKI UMIEJĘTNOŚCI
}

DOI: 10.33141/po.2020.04.05

\section{Gabriela Roszyk-Kowalska Janusz Kraśniak}

\section{Wprowadzenie}

W naukach o zarządzaniu kompetencje zajmują szczególne miejsce. Odgrywają istotną rolę w poszukiwaniu odpowiedzi na pytanie o źródła przewagi konkurencyjnej przedsiębiorstwa. Kompetencje kierownicze różnią się w zależności od branży, specyfiki pracy menedżera czy też wymagań, jakie stawia się kierownikowi. W związku z powyższym postuluje się kształtowanie kluczowych kompetencji, czyli tych kompetencji, których osoby zajmujące stanowiska kierownicze potrzebują do samorealizacji i rozwoju osobistego, integracji społecznej i zatrudnienia oraz bycia aktywnym w organizacji. Opracowanie zbioru kluczowych kompetencji staje się współcześnie celem strategicznym nie tylko na poziomie przedsiębiorstw, ale i na poziomie otoczenia społeczno-kulturowego. Kluczowe kompetencje kadry kierowniczej są szczególnie istotne w sektorze przedsiębiorstw Hi-Tech. Ze względu na pozytywnie ocenianą rolę tego sektora w stymulowaniu rozwoju społecznogospodarczego podejmowane są różnego rodzaju inicjatywy nakierowane na rozwój tego sektora. Inicjatywy te przyjmują postać instrumentów wsparcia, których celem jest ograniczenie barier rozwojowych oraz wzmacnianie możliwości rozwojowych przedsiębiorstw. Wykorzystanie tego wsparcia na płaszczyźnie przedsiębiorstw Hi-Tech związane jest także ze wzmacnianiem potencjału kadry kierowniczej. Jej kompetencje mają znaczący wpływ na odnoszony przez przedsiębiorstwo sukces lub porażkę. Waga problematyki skłoniła autorów artykułu do podjęcia badań zmierzających do identyfikacji kluczowych kompetencji kadry kierowniczej przedsiębiorstw sektora Hi-Tech oraz diagnozy luki umiejętności, stanowiących jeden z komponentów konstytuujących kluczowe kompetencje. Zarysowany powyżej problem stanowi podstawę sformułowania trzech pytań badawczych, które wyznaczają zakres postępowania badawczego przeprowadzonego w niniejszej publikacji:

1) jakie kluczowe kompetencje i umiejętności powinny charakteryzować kadrę kierowniczą przedsiębiorstw sektora Hi-Tech?

2) czy występuje luka umiejętności, tj. rozbieżność między pożądanym a rzeczywistym poziomem umiejętności kadry kierowniczej przedsiębiorstw Hi-Tech?
Przegląd Organizacji, Nr 4(963), 2020, s. 38-44

www.przegladorganizacji.pl

( ) Towarzystwo Naukowe Organizacji i Kierownictwa (TNOiK)
3) jakie działania przyczynić się mogą do minimalizacji zidentyfikowanej luki umiejętności?

$\mathrm{W}$ artykule przedstawiono wyniki postępowania badawczego zmierzającego do identyfikacji kluczowych kompetencji i umiejętności kadry kierowniczej przedsiębiorstw Hi-Tech, diagnozy poziomu luki pomiędzy stanem pożądanym a stanem rzeczywistym kluczowych umiejętności kadry kierowniczej oraz wskazano kierunki i sposoby ich doskonalenia.

\section{Umiejętności jako komponent kluczowych kompetencji}

$\mathbf{P}$ roblematyka kompetencji kadry kierowniczej od wielu lat stanowi przedmiot zainteresowań badaczy w kraju i za granicą. Jako pierwszy pojęcia kompetencji użył amerykański psycholog społeczny D. McClelland na przełomie lat 60. i 70. XX wieku. Przełomowym wydarzeniem dla interpretacji pojęcia kompetencji było pojawienie się definicji autorstwa R.E. Boyatzisa (1982), według którego kompetencje stanowią sumę ogólnej wiedzy, motywacji, cech, wyobrażeń o sobie, ról społecznych i umiejętności, które są niezbędne do prawidłowego wykonywania swojej pracy. Od tego czasu w literaturze przedmiotu pojawiło się wiele definicji kompetencji (Bugaj, Szarucki, 2019, s.7). Analiza definicji kompetencji pozwala na wyodrębnienie dwóch podejść w definiowaniu tego pojęcia. Pierwsze z nich wiąże kompetencje bezpośrednio z człowiekiem - jako kompetencje osobowe (Dessler, 2009, s. 362; Pocztowski, 2007, s. 117; Rostkowski, 2004, s. 41; Sajkiewicz, 2008, s. 119; Walkowiak, 2007, s. 19-20; Whiddett, Hollyforde, 2003, s. 13; Woodruffe, 2003, s. 94). Natomiast drugie z tych podejść wiąże kompetencje $\mathrm{z}$ wykonywaną pracą i/lub zajmowanym stanowiskiem (Cheetham, Chivers, 2005, s. 54; Dubois, Rothwell, 2008, s. 38; Jarosz-Lewandowska, 2016, s. 109; Listwan, 2006). Niezależnie od wyszczególnionych powyżej różnic większość autorów obu podejść zmaga się z koniecznością określenia komponentów kompetencji, czyli ze wskazaniem, co składa się na boyatzisowski "potencjał istniejący w człowieku" (Armstrong, 2002, s. 249), ujawniany w działaniu 
i pozwalający mu wykonywać pracę na odpowiednim poziomie. Najczęściej podkreślano, że głównymi komponentami kompetencji są wiedza, umiejętności i postawy kadry kierowniczej (Filipowicz, 2004, s. 17; Król, 2006, s. 82; Levy-Leboyer, 1997, s. 19; Oczkowska i in., 2018, s. 58; Oleksyn, 2006, s. 39; Rostkowski, 2014, s. 42). M. Kocór i A. Strzebińska (2010, s. 12) uznają, że kompetencje to wiedza, umiejętności i postawy związane z wykonywaniem określonych czynności, niezależnie od tego, w jakim trybie zostały nabyte i czy są potwierdzone $\mathrm{w}$ wyniku procedury walidacyjnej. Podobne ujęcie kompetencji prezentuje G. Bartkowiak (2011, s. 131) twierdząc, że kompetencje dotyczą zharmonizowanego wykorzystania zdolności, cech osobowości, a także nabytej wiedzy i umiejętności w celu doprowadzenia do pomyślnego wykonania złożonej misji w ramach przedsiębiorstwa. Zatem kompetencje dotyczą tego, co pracownik powinien robić i jak pracownik powinien to robić (Jarosz-Lewandowska, 2016, s. 109). Kompetencje menedżera natomiast stanowią jego potencjał obejmujący osobowość, wiedzę, umiejętności, postawy, doświadczenie i odpowiedzialność, który pozostaje w związku przyczynowo-skutkowym z zachowaniami decydującymi o sprawnym zarządzaniu (Tyrańska, 2018, s. 37).

Kompetencje różnią się w zależności od branży, specyfiki pracy czy też wymagań, jakie stawia się kierownikom. W związku z powyższym postuluje się, aby kształtować kluczowe kompetencje kadry kierowniczej, czyli takie, które w największym stopniu wpływają na skuteczność i efektywność w realizowaniu zadań zarządczych na stanowisku kierowniczym.

Takie ujęcie znalazło odzwierciedlenie także w zaleceniach Parlamentu Europejskiego i Rady Unii Europejskiej z dnia 18 grudnia 2006 roku w sprawie kluczowych kompetencji w procesie uczenia się przez całe życie (2006/962/WE). Parlament Europejski i Rada wskazują państwom członkowskim UE potrzebę rozwijania kluczowych kompetencji u wszystkich w ramach ich strategii uczenia się przez całe życie (Narzędzie do badania 11 kompetencji, 2013, s. 13). Kluczowe kompetencje są definiowane w tym dokumencie jako połączenie wiedzy, umiejętności i postaw odpowiednich do sytuacji.

W artykule przyjęto, że kompetencje kierownicze są szczególnym przypadkiem kompetencji w ogóle i oznaczają zdolność skutecznego wykorzystywania przez osobę zajmującą stanowisko kierownicze jej wiedzy, umiejętności i postaw do osiągnięcia celów organizacyjnych. Założono ponadto, że cechami kompetencji kierowniczych są:

- złożoność - kompetencje kierownicze konstytuowane są przez wiedzę, umiejętności i postawy kadry kierowniczej,

- operacyjność i celowość - kompetencje kierownicze przejawiają się $\mathrm{w}$ faktycznym zachowaniu i działaniu kierownika,

- sytuacyjność - kompetencje kierownicze zależą od kontekstu,
- zmienność - kompetencje kierownicze są dynamiczne i podlegają rozwojowi (Model kompetencji, 2017, s. 1), a także zmieniają się wraz z doświadczeniem oraz rozwojem zawodowym i życiowym kierownika,

- mierzalność - można je zdefiniować, określić wskaźniki do ich obserwacji, pomiaru i oceny (Orlińska-Gondor, 2006, s. 171-174; Stabryła, 2011, s. 106).

Jednym z ważnych komponentów kluczowych kompetencji są umiejętności. Należy podkreślić, że nie ma jednoznaczności w określaniu wzajemnych relacji, jakie zachodzą między umiejętnościami a kompetencjami (Czapla, 2011, s. 13). Umiejętności dotyczą tego, co pracownik rzeczywiście potrafi robić i często bywają utożsamiane z doświadczeniem lub zdolnościami do działania. Umiejętności oznaczają znajomość konkretnych zagadnień i biegłość w wykonywaniu zadań z nimi związanych (Roszyk-Kowalska, 2018, s. 52). Przyjmując, że umiejętności to zdolności do sprawnego działania kierownika w organizacji, stwierdzić należy jednocześnie, że brak jest jednomyślności wśród badaczy zmierzających do zdefiniowania pewnego uniwersalnego zbioru umiejętności kadry kierowniczej. Ponadto zauważa się brak precyzji pojęciowej. Pomimo wskazanych trudności postuluje się wyznaczanie tak zwanych kluczowych umiejętności kierowniczych, czyli tych umiejętności, które są szczególnie istotne dla osoby zajmującej stanowisko kierownicze $\mathrm{w}$ przedsiębiorstwie. Warto nadmienić, że w wielu krajach wprowadzono w życie programy, które przyczyniają się do kształtowania kluczowych umiejętności. Znalazło to również wyraz w reformie polskiej oświaty. Przy opracowywaniu projektu podstawy programowej ogłoszonej w Rozporządzeniu Ministra Edukacji Narodowej z dnia 23 grudnia 2008 roku w sprawie podstawy programowej wychowywania przedszkolnego oraz kształcenia ogólnego w poszczególnych typach szkół uwzględniono także zalecenie Parlamentu Europejskiego i Rady z 18 grudnia 2006 roku w sprawie kluczowych umiejętności w procesie uczenia się przez całe życie. Pojęcie kluczowych umiejętności jest rozpowszechnione w Polsce od roku 1995, w związku z pracami nad na przykład programem KREATOR. Kluczowe umiejętności są tam definiowane jako umiejętności ponadprzedmiotowe. Na potrzeby tego programu zdefiniowano pięć umiejętności, do których zaliczono: umiejętność planowania, organizowania i oceniania własnego uczenia się; umiejętność skutecznego komunikowania się w różnych sytuacjach; umiejętność efektywnego współdziałania w grupie; umiejętność rozwiązywania problemów w twórczy sposób oraz sprawne posługiwanie się technologią informacyjną (Charakterystyka ..., 2014).

Niezależnie od liczby formułowanych kluczowych umiejętności należy pamiętać, że od pozostałych umiejętności odróżniają je pewne cechy. Kluczowe umiejętności odgrywają szczególną rolę w procesie uczenia się, są wyjątkowo istotne do osiągania przez człowieka celów społecznych oraz są niezbędne na stanowiskach pracy, 
gdyż umożliwiają rozwój kluczowych kompetencji, co jest szczególnie istotne w pracy kierowniczej.

\section{Metoda badawcza}

$\mathbf{P}$ rocedura postępowania badawczego zmierzająca do identyfikacji kluczowych kompetencji oraz kluczowych umiejętności kadry kierowniczej przedsiębiorstw sektora Hi-Tech, a także diagnozy luki umiejętności obejmowała trzy etapy:

Etap 1. Identyfikacja kluczowych kompetencji przedsiębiorstwa sektora Hi-Tech na podstawie opinii kadry kierowniczej i opinii ekspertów reprezentujących wybrane ośrodki akademickie w Polsce oraz praktykę gospodarczą.

Etap 2. Identyfikacja zmiennych charakteryzujących kluczowe umiejętności przedsiębiorstwa sektora Hi-Tech na podstawie opinii kadry kierowniczej i opinii ekspertów.

Etap 3. Identyfikacja luki umiejętności rozumianej jako różnica pomiędzy stanem oczekiwanym określanym na podstawie wskazań kadry kierowniczej szczebla strategicznego a stanem rzeczywistym określanym na podstawie wskazań kadry kierowniczej szczebla taktycznego i operacyjnego. Do oceny stanu oczekiwanego i rzeczywistego kluczowych umiejętności posłużono się skalą czterostopniową ( 3 - umiejętność bardzo ważna, 2 - średnie znaczenie umiejętności, 1 - małe znaczenie umiejętności, 0 - umiejętność nieistotna).

Badaniem objęto kadrę kierowniczą wszystkich szczebli zarządzania przedsiębiorstw $\mathrm{Hi}$-Tech funkcjonujących na terenie Polski. Dane otrzymane w postępowaniu badawczym przy wykorzystaniu wywiadu bezpośredniego, metody eksperckiej i kwestionariusza ankiety podlegały porządkowaniu, grupowaniu i analizie. W tym celu zastosowano następujące narzędzia statystyczne:

- techniki badające rzetelność ankiety: współczynnik zgodności ocen M.G. Kendalla, wskaźnik rzetelności alfa Cronbacha i test Kruskala-Wallisa;

- parametry i metody analizy służące opisowi próby badawczej: wskaźniki struktury, średnie, mediany, odchylenia standardowe, badanie normalności rozkładu za pomocą testu Kołmogorowa-Smirnowa;

- parametry i metody opisujące postawy i umiejętności w ramach analizowanych obszarów kompetencji: średnia, test $t$-Studenta dla średniej, test $t$-Studenta dla prób zależnych, test na równość wskaźników struktury oraz test $U$ Manna-Whitneya;
- parametry i metody badające związki pomiędzy analizowanymi zmiennymi oraz opisujące sektor wysokich technologii: współczynnik korelacji rang Spearmana, współczynnik korelacji liniowej Pearsona, testy istotności współczynników korelacji, analiza regresji (liniowej dwu i wielu zmiennych) i trend liniowy.

Do analizy uzyskanych wyników wykorzystano pakiet statystyczny STATISTICA 10 PL firmy StatSoft. Przyjętym we wnioskowaniu poziomem istotności była wartość alfa $=0,05$. Strukturę próby badawczej przedstawiono w tabeli 1.

\section{Wyniki badań}

ierownikom i ekspertom uczestniczącym w badaniu przedstawiono zbiór 18 potencjalnych kluczowych kompetencji, które zidentyfikowano na podstawie studiów literaturowych i doświadczeń praktycznych. Biorąc pod uwagę opinie kadry kierowniczej i opinie ekspertów oraz medianę policzoną dla wszystkich istotności - w przypadku 18 czynników (dla których najniższa ważność to 3,64 , a najwyższa 4,55 ) - połowa z czynników poddanych badaniu eksperckiemu nie przekraczała wartości 4,365 (tyle wynosi średnia między istotnością ósmego i dziewiątego czynnika), a połowa ma wartości nie niższe niż 4,365, zdecydowano, że na dalszym etapie badań zostanie uwzględnionych tylko tych dziewięć czynników, których istotność przekroczyła medianę, identyfikowanych jako kluczowe kompetencje przedsiębiorstw Hi-Tech. Na podstawie pierwszego etapu postępowania badawczego do kluczowych kompetencji przedsiębiorstw sektora Hi-Tech zaliczono:

- wysoki poziom przedsiębiorczości,

- wysoki poziom kreatywności,

- efektywne procesy pozyskiwania, wykorzystania i dzielenia się wiedzą,

- wysoki poziom wykorzystania potencjału pracy zespołowej,

- wysoki poziom innowacyjności,

- zdolność do współpracy w układach relacyjnych,

- wysoką samodzielność pracowników,

- umiejętne zarządzanie działalnością B+R,

- oparcie systemów komunikacyjnych na nowoczesnych technologiach informatycznych.

Tabela 1. Struktura próby badawczej według liczby osób zatrudnionych na stanowiskach kierowniczych

\begin{tabular}{|l|c|c|c|c|c|}
\hline \multicolumn{1}{|c|}{ Szczebel zarządzania } & N ważnych & Średnia & Minimum & Maksimum & Odchylenie standardowe \\
\hline Strategiczny & 140 & 49,80714 & 20 & 250 & 42,83310 \\
\hline Taktyczny & 220 & 54,03636 & 20 & 280 & 49,59819 \\
\hline Operacyjny & 144 & 56,75524 & 20 & 280 & 54,25789 \\
\hline Ogółem & 504 & 53,63221 & 20 & 280 & 49,20222 \\
\hline
\end{tabular}


Tabela 2. Przekształcenie kluczowych kompetencji przedsiębiorstw Hi-Tech w zbiór zmiennych charakteryzujących kluczowe umiejętności

\begin{tabular}{|c|c|}
\hline Kluczowa kompetencja & Kluczowe umiejętności \\
\hline \multirow{3}{*}{ przedsiębiorczość } & łatwość podejmowania decyzji (1) \\
\hline & $\begin{array}{l}\text { porównywanie rzeczywistych wyników przedsiębiorstwa } \\
\text { z zaplanowanymi (2) }\end{array}$ \\
\hline & planowanie własnego działania i samomotywacja (3) \\
\hline \multirow{3}{*}{ kreatywność } & tworzenie i wdrażanie nowych rozwiązań (4) \\
\hline & dokonywanie wizualizacji (5) \\
\hline & formułowanie wniosków na podstawie własnych błędów (6) \\
\hline \multirow{3}{*}{ zarządzanie wiedzą } & analizowanie zasobów przedsiębiorstwa i otoczenia (7) \\
\hline & trafne podejmowanie decyzji personalnych (8) \\
\hline & pozytywne nastawienie w kontaktach z innymi (9) \\
\hline \multirow{3}{*}{ praca w zespole } & motywowanie (10) \\
\hline & dobre współdziałanie z innymi (11) \\
\hline & trafna diagnoza emocji w zespole (12) \\
\hline \multirow{3}{*}{ innowacyjność } & myślenie analityczne (13) \\
\hline & myślenie syntetyczne (14) \\
\hline & myślenie prognostyczne (15) \\
\hline \multirow{3}{*}{ współpraca w układach relacyjnych } & $\begin{array}{l}\text { kształtowanie właściwych stosunków z otoczeniem bliższym } \\
\text { i dalszym (16) }\end{array}$ \\
\hline & $\begin{array}{l}\text { zarządzanie przedsiębiorstwem w otoczeniu } \\
\text { wielokulturowym (17) }\end{array}$ \\
\hline & troska o pozytywny wizerunek przedsiębiorstwa (18) \\
\hline \multirow{3}{*}{ usamodzielnianie pracowników } & organizowanie zasobów niezbędnych do realizacji zdań (19) \\
\hline & organizowanie stanowisk pracy (20) \\
\hline & korygowanie własnych i cudzych błędów (21) \\
\hline \multirow{3}{*}{ zarządzanie działalnością B+R } & pozyskiwanie funduszy z zewnątrz przedsiębiorstwa (22) \\
\hline & właściwe zarządzanie finansami (23) \\
\hline & dysponowanie posiadaną wiedzą (24) \\
\hline \multirow{3}{*}{$\begin{array}{l}\text { opieranie systemów komunikacyjnych } \\
\text { na nowoczesnych technologiach } \\
\text { informatycznych }\end{array}$} & szybka i łatwa wymiana informacji (25) \\
\hline & sprawna obsługa technologii (26) \\
\hline & $\begin{array}{l}\text { rozpoznawanie trendów w rozwoju nowoczesnych technologii } \\
\text { informatycznych (27) }\end{array}$ \\
\hline
\end{tabular}

Źródło: opracowanie własne

W ramach drugiego etapu badań zmierzano do przekształcenia kluczowych kompetencji przedsiębiorstw Hi-Tech w zbiór zmiennych charakteryzujących kluczowe umiejętności. Na podstawie opinii kadry kierowniczej, opinii ekspertów oraz mediany policzonej dla wszystkich istotności spośród zbioru 54 potencjalnych kluczowych umiejętności wytypowano zbiór 27 umiejętności. Przekształcenie zmiennych charakteryzujących kluczowe kompetencje w zbiór zmiennych charakteryzujących kluczowe umiejętności zaprezentowano w tabeli 2 i na rysunku 1. 


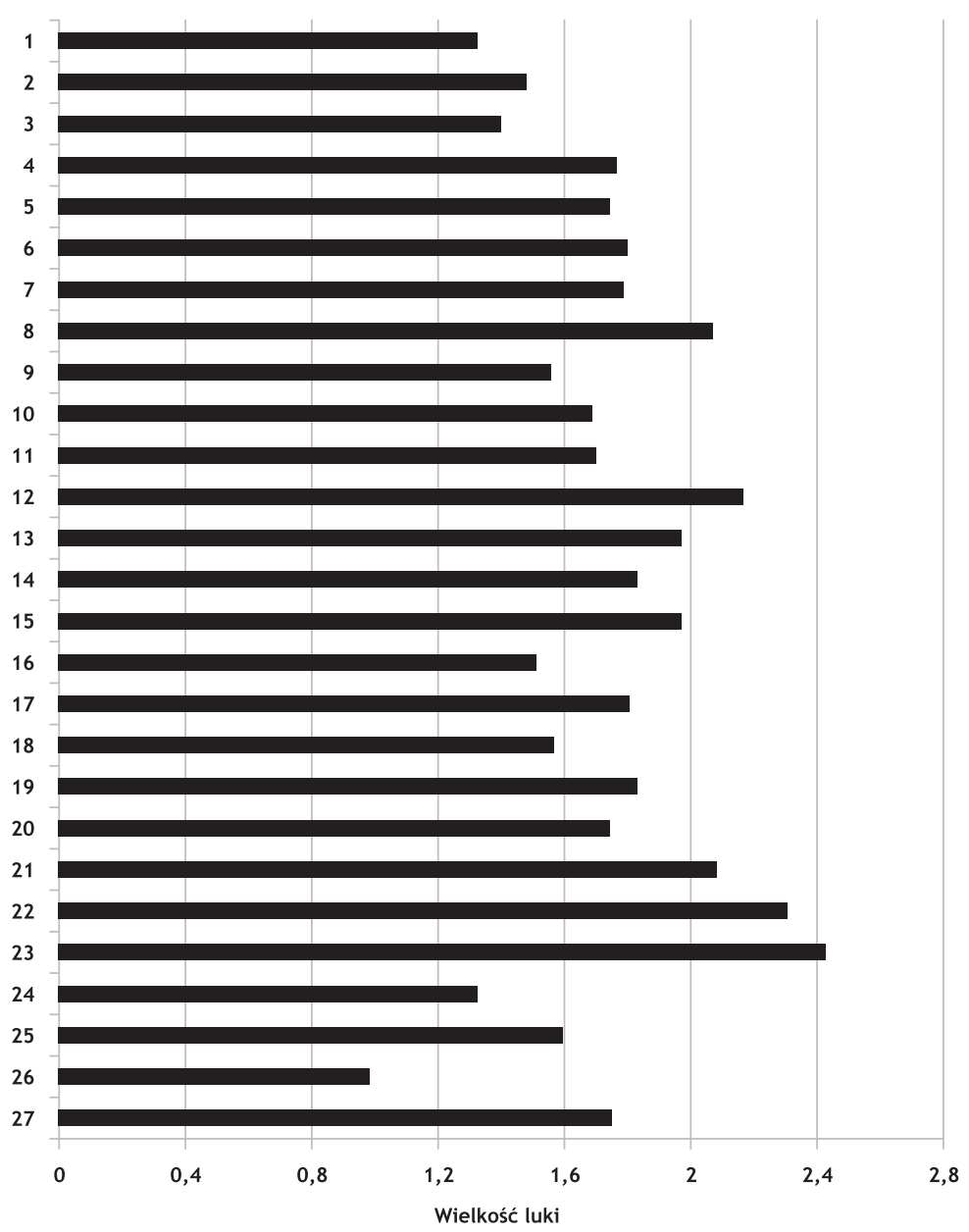

Rys. 1. Wielkość luki pomiędzy stanem oczekiwanym a stanem rzeczywistym kluczowych umiejętności kadry kierowniczej w przedsiębiorstwach $\mathrm{Hi}$-Tech Źródło: opracowanie własne

Do oceny istotności luki kluczowych umiejętności został zastosowany test U Manna-Whitneya. Analizując wielkość luki pomiędzy stanem oczekiwanym a stanem rzeczywistym kluczowych umiejętności kadry kierowniczej w przedsiębiorstwach zaawansowanych technologii (rys. 1), sformułowano następujące wnioski:

- przedsiębiorczość - największa luka występuje w zakresie umiejętności porównywania rzeczywistych wyników przedsiębiorstwa z zaplanowany$\mathrm{mi}$, najmniejsza natomiast dotyczy łatwości podejmowania decyzji;

- kreatywność - największa luka występuje w umiejętności formułowania wniosków na podstawie popełnionych przez kadrę kierowniczą błędów, a najmniejsza dotyczy umiejętności dokonywania wizualizacji;

- zarządzanie wiedzą - największa luka występuje $\mathrm{w}$ trafnym podejmowaniu decyzji personalnych, a najmniejsza dotyczy umiejętności pozytywnego nastawienia $\mathrm{w}$ kontaktach $\mathrm{z}$ innymi;

- praca w zespole - największa luka występuje w ocenie trafnej diagnozy emocji panujących w zespole, a najmniejsza dotyczy umiejętności motywowania uczestników organizacji;
- innowacyjność - największa luka występuje w umiejętności myślenia analitycznego i prognostycznego, a najmniejsza dotyczy umiejętności myślenia syntetycznego;

- współpraca w układach relacyjnych - największa luka występuje w umiejętności zarządzania przedsiębiorstwem w otoczeniu wielokulturowym, a najmniejsza dotyczy umiejętności kształtowania właściwych stosunków z otoczeniem bliższym i dalszym;

- usamodzielnianie pracowników - największa luka występuje w umiejętności korygowania własnych i cudzych błędów, a najmniejsza dotyczy umiejętności w zakresie organizowania stanowisk pracy;

- zarządzanie działalnością B+R - największa luka występuje w umiejętności właściwego zarządzania finansami, a najmniejsza dotyczy umiejętności dysponowania posiadaną wiedzą;

- opieranie systemów komunikacyjnych na nowoczesnych technologiach informatycznych - największa luka występuje w ocenie umiejętności rozpoznawania trendów w rozwoju nowoczesnych technologii informatycznych, a najmniejsza dotyczy kluczowej umiejętności, jaką jest obsługa stosowanych przez badane przedsiębiorstwa technologii. 
Konkludując, największa luka między stanem oczekiwanym a rzeczywistym w przedsiębiorstwach w zakresie kluczowych umiejętności dotyczy właściwego zarządzania finansami, pozyskiwania funduszy z zewnątrz przedsiębiorstwa (luka dotyczy kluczowej kompetencji zarządzania działalnością $\mathrm{B}+\mathrm{R}$ ) oraz trafnej diagnozy emocji panujących w zespole (luka dotyczy kluczowej kompetencji pracy w zespole) i trafnego podejmowania decyzji personalnych (luka dotyczy kluczowej kompetencji zarządzania wiedzą).

W celu minimalizacji zidentyfikowanej luki umiejętności postuluje się podjęcie działań, które przyczynić się mogą do doskonalenia tych umiejętności. Jednak ważna jest świadomość, że samo nabycie umiejętności nie jest warunkiem wystarczającym do tego, aby kierownik stał się kierownikiem kompetentnym. Działania doskonalące umiejętności kadry kierowniczej przedsiębiorstw Hi-Tech powinny obejmować:

- przedsiębiorczość - doskonalenie wśród kadry kierowniczej umiejętności porównywania rzeczywistych wyników przedsiębiorstwa z zaplanowanymi oraz większej koncentracji tej kadry na planowaniu własnego działania i samomotywacji;

- kreatywność - doskonalenie umiejętności identyfikowania popełnianych przez siebie błędów, podejmowanie prób ich naprawy, a także przyznawania się do nich oraz większego przekonania, że porażka daje możliwości rozpoczęcia działania w sposób bardziej przemyślany;

- zarządzanie wiedzą - doskonalenie procesu podejmowania decyzji kadrowych zmierzających m.in. do pozyskania pracowników nastawionych na zapewnienie sukcesu przedsiębiorstw, w których będą zatrudnieni;

- praca w zespole - doskonalenie umiejętności trafniejszej diagnozy emocji panujących w zespole oraz dążenie do zbudowania relacji ułatwiających współdziałanie $\mathrm{z}$ innymi;

- innowacyjność - doskonalenie umiejętności myślenia analitycznego i prognostycznego w powiązaniu $\mathrm{z}$ bardziej otwartą postawą wobec innowacji;

- współpraca w układach relacyjnych - doskonalenie umiejętności podejmowania decyzji w środowisku wielokulturowym, tolerancję dla odmienności kulturowych i narodowych oraz większą dbałość o zapewnienie pozytywnego wizerunku przedsiębiorstwa;

- usamodzielnianie pracowników - podejmowanie w większym zakresie działań zmierzających do korygowania przez kadrę kierowniczą własnych i cudzych błędów oraz doskonalenia pracy pod presją czasu a także radzenia sobie w sytuacjach trudnych;

- zarządzanie działalnością B+R - podnoszenie umiejętności właściwego zarządzania finansami oraz zintensyfikowanie działań zmierzających po pozyskania różnych form wsparcia działalności $\mathrm{B}+\mathrm{R}$ funduszami pochodzącymi spoza przedsiębiorstwa;
- opieranie systemów komunikacyjnych na nowoczesnych technologiach informatycznych - zastosowanie bodźców zachęcających do uczenia się, co ułatwić powinno rozpoznawanie trendów towarzyszących rozwojowi nowoczesnych technologii informatycznych.

\section{Podsumowanie}

W e współczesnych przedsiębiorstwach kluczowe kompetencje kadry kierowniczej są szczególnie istotnym zasobem. Ciągłe dążenie do doskonalenia kluczowych kompetencji kadry kierowniczej w przedsiębiorstwach sektora zaawansowanych technologii poprzez podnoszenie poziomu kluczowych umiejętności należy taktować jako swoiste wyzwanie organizacyjne, wokół którego należy skupić działania uczestników organizacji. Działania te mogą przyczynić się do wzrostu sprawności i konkurencyjności polskich przedsiębiorstw sektora Hi-Tech. Wyniki badań wskazują na zróżnicowany poziom umiejętności kadry kierowniczej. Najwyższy poziom umiejętności charakteryzuje kluczowe kompetencje: przedsiębiorczość i wykorzystywanie systemów komunikacyjnych w oparciu o nowoczesne technologie informatyczne. Za niepokojące zjawisko należy uznać stosunkowo niski poziom umiejętności charakteryzujących kluczowe kompetencje: zarządzanie działalnością $\mathrm{B}+\mathrm{R}$, praca $\mathrm{w}$ zespole oraz zarządzanie wiedzą. W zakresie tych kluczowych kompetencji umiejętności kadry kierowniczej kształtują się na najniższym poziomie. Poziom tych umiejętności można zinterpretować jako stan luki umiejętności wymagający podjęcia szczególnie intensywnych działań nakierowanych na ich doskonalenie. Zaprezentowane wyniki badań dotyczące luki umiejętności są częścią szerszego projektu badawczego zmierzającego do identyfikacji i diagnozy poziomu kluczowych kompetencji kadry kierowniczej zatrudnionej w przedsiębiorstwach $\mathrm{Hi}$-Tech. W ramach projektu badawczego podjęto także próbę identyfikacji pozostałych komponentów kluczowych kompetencji, tj. poziomu wiedzy i postaw kadry kierowniczej przedsiębiorstw Hi-Tech.

\author{
dr hab. Gabriela Roszyk-Kowalska, prof. uczelni \\ Uniwersytet Ekonomiczny w Poznaniu \\ Instytut Zarządzania \\ ORCID: 0000-0002-8424-471X \\ e-mail: g.roszyk-kowalska@ue.poznan.pl
}

dr hab. Janusz Kraśniak, prof. uczelni
Uniwersytet Ekonomiczny w Poznaniu
Instytut Zarządzania
ORCID: 0000-0003-1864-9687
e-mail: janusz.krasniak@ue.poznan.pl 


\section{Bibliografia}

[1] Armstrong M. (2002), Zarządzanie zasobami ludzkimi, Oficyna Wydawnicza, Kraków.

[2] Bartkowiak G. (2011), Społeczna odpowiedzialność biznesu $w$ aspekcie teoretycznym i empirycznym, Difin, Warszawa.

[3] Boyatzis R.E. (1982), The Component Manager. A Model for Effective Performance, John Wiley \& Sons, Canada.

[4] Bugaj J., Szarucki M. (2019), Doskonałość naukowa oraz doskonałość dydaktyczna jako kluczowe kompetencje uczelni publicznych w Polsce, „Przegląd Organizacji”, Nr 2, s. 7-14.

[5] Charakterystyka umiejętności kluczowych programu KREATOR, 2014, http://www.szkolnictwo.pl/index.php?id=PU4074/, data dostępu: 8.10.2019 r.

[6] Cheetham G., Chivers G. (2005), Professions, Competence and Informal Learning, Edward Elgar Publishing, Cheletenham.

[7] Czapla T.P. (2011), Modelowanie kompetencji kierowniczych $w$ organizacji, Wydawnictwo Uniwersytetu Łódzkiego, Łódź.

[8] Dessler A.M. (2009), Framework for Human Resources Management, Prentice_hall, Upper Saddle River.

[9] Dubois D.D., Rothwell W.J. (2008), Zarzadzanie zasobami ludzkimi oparte na kompetencjach, Helion, Gliwice.

[10] Filipowicz G. (2004), Zarządzanie kompetencjami zawodowymi, PWE, Warszawa.

[11] Jarosz-Lewandowska D. (2016), Kompetencje polskiej kadry logistycznej w świetle wyników badań, Zeszyty Naukowe Politechniki Śląskiej, Nr 1955, Seria: Organizacja i Zarządzanie, z. 92, s. 107-118.

[12] Kocór M., Strzebińska A. (2010), Jakich pracowników potrzebuja polscy pracodawcy? PARP, Warszawa.

[13] Król H. (2006), Podstawy koncepcji zarządzania zasobami ludzkimi, [w:] H. Król, A. Ludwiczyńska, Zarządzanie zasobami ludzkimi, WN PWN, Warszawa, s. 50-91.

[14] Król M. (2013), Kompetencje interpersonalne i cechy innowacyjnego menedżera projektów, „Współczesne Zarządzanie", Nr 2, s. 190-199.

[15] Levy-Leboyer C. (1997), Kierowanie kompetencjami, Bilanse doświadczeń zawodowych, Poltext, Warszawa.

[16] Listwan T. (red.), (2006), Stownik zarządzania kadrami, Wydawnictwo C.H. Beck, Warszawa.

[17] Model kompetencji, 2017, a.umed.pl/pl_akt_tmp/2014/ UMED_Model_Kompetencyj-ny_v10.docx, data dostępu: 9.10.2019 r.

[18] Narzędzie do badania 11 kompetencji. 2013, http://www. jestemprzedsiebiorczy.pl/att/Narzedzie-do-badania-11-kompetencji.pdf/, data dostępu: 7.10.2019 r.

[19] Oczkowska R., Lula P., Wiśniewska S. (2018), Kompetencje pracowników działów HR - badania oczekiwań pracodawców na podstawie analizy ofert pracy, „Przegląd Organizacji”, Nr 12, s. 57-63.

[20] Oleksyn T. (2006), Zarzadzanie kompetencjami. Teoria i praktyka, Oficyna Ekonomiczna, Kraków.

[21] Orlińska-Gondor A. (2006), Zarządzanie ludźmi oparte na pojęciu kompetencji, [w:] L. Zbiegień-Maciąg (red.), Nowe tendencje i wyzwania w zarządzaniu personelem, Wolters Kluwer, Kraków, s. 168-191.
[22] Pocztowski A. (2007), Zarzadzanie zasobami ludzkimi, PWE, Warszawa.

[23] Rostkowski T. (2014), Model kompetencyjny organizacji, [w:] M. Juchnowicz, Zarządzanie kapitałem ludzkim. Procesy - narzędzia - aplikacje, PWE, Warszawa, s. 38-63.

[24] Rostkowski T. (red.), (2004), Nowoczesne metody zarządzania zasobami ludzkimi, Difin, Warszawa.

[25] Roszyk-Kowalska G. (2018), Kompetencje kadry kierowniczej $w$ przedsiębiorstwach wysokich technologii, Wydawnictwo Uniwersytetu Ekonomicznego w Poznaniu, Poznań.

[26] Rozporządzenie Ministra Edukacji Narodowej z 23 grudnia 2008 r. w sprawie podstawy programowej wychowania przedszkolnego oraz kształcenia ogólnego w poszczególnych typach szkół, Dz.U. 2009, Nr 4, poz. 17.

[27] Sajkiewicz A. (2008), Kompetencje menedżerów w organizacji uczacej się, Difin, Warszawa.

[28] Stabryła A. (red.), (2011), Przegląd problemów doskonalenia systemów zarządzania przedsiębiorstwem, Mfiles.pl, Kraków.

[29] Tyrańska M. (2018), Ocena kompetencji menedżerskich - propozycja metodyczna, „Przegląd Organizacji”, Nr 10, s. $36-42$.

[30] Walkowiak R. (2007), Zarzadzanie zasobami ludzkimi. Kompetencje, nowe trendy, efektywność, Dom Organizatora, Toruń.

[31] Whiddett S., Hollyforde S. (2003), Modele kompetencyjne w zarzadzaniu zasobami ludzkimi, Oficyna Ekonomiczna, Kraków.

[32] Woodruffe C. (2003), Ośrodki oceny i rozwoju. Narzędzia analizy i doskonalenia kompetencji pracowników, Oficyna Wydawnicza, Kraków.

\section{Core Competencies of $\mathrm{Hi}$-Tech Enterprises Management Staff. Diagnosis of Skill Gap}

\section{Summary}

Core competencies of the managerial staff are particularly important in the Hi-Tech sector. The significance of the issues prompted the authors of the article to undertake research aimed at identifying and assessing core competencies of the management staff in enterprises of the Hi-Tech sector. The findings of the study indicate that the biggest gap between the expected and actual state of affairs in the surveyed companies in terms of core skills applies to proper financial management, external fund-raising (a core competence in R\&D management), as well as accurate diagnosis of emotions prevailing in the team (a core competence in teamwork) and apt personnel decisions (a core competence in knowledge management).

\section{Keywords}

core competencies, managerial competences, managerial skills, enterprises in the Hi-Tech sector 